\title{
KONSTRUKSI KAUSATIF ANALITIK DALAM BAHASA INGGRIS DAN BAHASA INDONESIA
}

\author{
Sutar Oktaviana Tampubolon, Mulyadi
}

Surel: sutaroktaviana@gmail.com

\begin{abstract}
This study discusses the causative constructions of analytics in English and Indonesian. The purpose of this study describes the forms, similarities and differences in Indonesian and English. This research method using descriptive qualitative, with technique refer and note. The results of this study explain the form of the word verb causes (causes) in English in Indonesian verb form word.
\end{abstract}

Keywords: Causative Analytic, English and Indonesian language.

\begin{abstract}
ABSTRAK
Penelitian ini membahas tentang konstruksi kausatif analitik dalam bahasa inggris dan bahasa Indonesia. Tujuan penelitian ini mendeskripsikan bentuk, persamaan dan perbedaan dalam bahasa Indonesia dan bahasa inggris. Metode penelitian ini menggunakan deskriptif kualitatif, dengan teknik simak dan catat. Hasil penelitian ini menjelaskan tentang bentuk kata verba cause (menyebabkan) didalam bahasa inggris sedangkan dalam bahasa Indonesia bentuk kata verba adalah membuat dan menyebabkan.
\end{abstract}

Kata Kunci: kausatif analitik, bahasa inggris dan bahasa Indonesia.

\section{PENDAHULUAN}

Istilah kausatif digunakan untuk menggambarkan situasi atau kejadian yang terdapat didalam suatu konstruksi. Cara termudah untuk mendeskripsikan konstruksi kausatif adalah dengan menggambarkan situasi kausatif itu sendiri (Shibatani 1967: 1). Situasi kausatif adalah situasi yang terdiri atas dua kejadian yang saling berhubungan, yang satu menunjukkan sebab dan yang lain menyatakan akibat.

Hubungan antara sebab dan akibat tersebut ialah munculnya akibat yang sepenuhnya bergantung pada munculnya sebab dalam arti akibat tidak mungkin terjadi pada suatu waktu jika sebab itu belum terjadi. Kalimat kausatif merupakan salah satu fenomena kesemestaan bahasa. Dengan demikian bahasa inggris dan bahasa Indonesia memiliki ungkapan yang digunakan untuk menyampaikan makna kausatif. Comrie (1989: 165) mengatakan bahwa dalam situasi kausatif terdapat dua komponen yaitu sebab (the cause) dan akibat yang dihasilkan (result). Konstruksi kausatif erat kaitanya dengan komponen sebab memberi pengaruh sehingga timbul akibat pada komponen akibat. Dua komponen tersebut merupakan situasi mikro yang apabila digabungkan akan membentuk situasi makro yang disebut situasi kausatif. Tipe-tipe konstruksi kausatif yang dimiliki 
oleh setiap bahasa berbeda satu dengan yang lainnya. Ada bahasa yang memiliki ketiga tipe konstruksi (kausatif leksiskal, kausatif morfologis dan kausatif analitik) dan ada juga bahasa yang hanya memiliki dua tipe konstruksi kausatif; kausatif leksikal dan kausatif analitik. Bahasa yang memiliki ketiga tipe konstruksi pada umumnya merupakan bahasa yang bertipe aglutinasi karena bahasa bertipe ini mempunyai afiks yang dapat dilekatkan pada verba yang berfungsi menaikkan atau menurunkan valensi verba. Sementara, bahasa yang hanya memiliki dua tipe kausatif merupakan bahasa yang bertipe isolasi karena bahasa tersebut pada umumnya tidak memiliki afiks yang berfungsi untuk menaikkan atau menurunkan valensi verba.

Senada dengan Shibatani, Comri (1989:165) menyatakan bahwa suatu konstruksi kausatif melibatkan dua komponen situasi atau kejadian, yaitu sebab dan akibat. Sebab dan akibat ini selanjutnya disebut situasi mikro yang kemudian bergabung untuk membentuk satu situasi makro, yaitu kausatif itu sendiri.

Definisi konstruksi kausatif di atas menunjukkan komponen sebab memberi pengaruh sehingga timbul akibat pada komponen akibat. Dua komponen tersebut merupakan situasi mikro yang apabila digabungkan akan membentuk situasi makro yang disebut situasi kausatif. Hal tersebut dapat dilihat pada contoh berikut:

(1) The bus's failure to come caused me to late for the meeting.

(Kegagalan bus yang terjadi membuat saya terlambat menghadiri rapat) .

(2) Antha makes me wait at juanda international airport.

(Antha membuat saya menunggu di bandara juanda internasional)

Pada contoh kalimat (1) diatas kata membuat (caused) didalam bahasa inggris menyatakan tentang sebab-akibat, sedangkan pada contoh kalimat (2) kata kerja membuat (makes) menyatakan sebab. Dalam bahasa Indonesia juga dikenal tipetipe kausatif seperti yang dikemukakan oleh Comrie di atas.

Dari pemaparan contohcontoh di atas, terlihat perbedaan bentuk verba kausatif dan maknanya dalam bahasa Inggris dan bahasa Indonesia. Hal ini menimbulkan minat penulis untuk meneliti verba kausatif dalam bahasa Inggris dan bahasa Indonesia. Penelitian ini dimaksudkan untuk mengamati bentuk kalimat verba kausatif dalam bahasa inggris dan bahasa indonesia

\section{METODE PENELITIAN}

Metode penelitian ini menggunakan kualitatif deskriptif. Menurut Nazir (1988), metode deskriptif merupakan suatu metode dalam meneliti status sekelompok manusia, suatu objek, suatu set kondisi, suatu sistem pemikiran 
ataupun suatu kelas peristiwa pada masa sekarang. Tujuan dari penelitian deskriptif ini adalah untuk membuat deskripsi, gambaran, atau lukisan secara sistematis, faktual dan akurat mengenai fakta-fakta, sifatsifat serta hubungan antarfenomena yang diselidiki, tentang bagaimana bentuk kalimat verba didalam bahasa inggris dan bahasa Indonesia. Sumber data dalam kajian ini diperoleh dari sumber tertulis yaitu jurnal yang membahas mengenai kalimat kausatif. Penelitian ini menggunakan metode kualitatif deskriptif dengan cara menyimak dan catat. Penelitian ini berdasarkan pendapat bahwa setiap bahasa didunia ini memiliki konstruksi kausatif (Whaley, 1997: 192). Metode penyajian hasil analisis dalam penelitian ini menggunakan metode penyajian informal. Metode penyajian informal adalah merumusan dengan kata-kata biasa, walaupun denganterminologi yang sifatnya teknis. (Sudaryanto, 2015: 145).

\section{HASIL PENELITIAN DAN PEMBAHASAN}

Bentuk kalimat konstruksi kausatif analitik dalam bahasa Indonesia dan bahsa Inggris. Comrie (1981: 158--160; 1989:165--171) menyatakan bahwa konstruksi kausatif dibedakan menjadi tiga, yaitu kausatif analitik, kausatif morfologis, dan kausatif leksikal. Dari ketiga konstruksi kausatif yang dikemukan oleh Comrie (1981: 158-160; 1989:165--171) tersebut, BKm hanya memiliki konstruksi kausatif leksikal dan konstruksi kausatif analitik. Kausatif analitik dalam bahasa Indonesia dapat dibentuk dengan menggunakan verba membuat. Selain itu, verba menyebabkan dan membikin juga dapat digunakan sebagai pemarkah kausatif analitik ini. Akan tetapi, dalam tulisan ini hanya akan dibahas verba membuat. Perhatikan contoh berikut.

(1). a. Renaldi tertawa terbahakbahak (verba intransitif tertawa sebagai dasar)

b. Peristiwa itu membuatnya tertawa terbahak-bahak

(2) a. Pedagang selalu mencari untung (verba transitif mencari sebagai dasar)

b. Rumah yang mewah itu membuat pedagang selalu mencari untung

Pada contoh di atas dapat dilihat bahwa konstruksi kausatif (1b) dan (2b) terbentuk dari konstruksi nonkausatif (1a) dan (2a). Dilihat dari jenis predikatnya, predikat konstruksi nonkausatif (6a) berupa verba intransitif, sedangkan konstruksi nonkausatif (2a) berupa verba transitif. Dari data di atas kita dapat mengetahui bahwa perubahan konstruksi nonkausatif, baik konstruksi dengan predikat verba dasar intransitif (1a) maupun dengan verba transitif (2a), menjadi konstruksi kausatif (1b) dan (2b) mengharuskan kehadiran verba kausatif membuat. Kehadiran verba kausatif membuat ini menyebabkan 
konstruksi kausatif analitik ini memiliki dua predikat dalam setiap konstruksinya. Akibat dari penambahan verba kausatif membuat ini adalah adanya penambahan satu argument yang berfungsi sebagai penyebab. Kehadiran verba membuat pada kalimat (1b) menuntut kehadiran Peristiwa itu sebagai penyebab sehingga memunculkan akibat Renaldi tertawa terbahakbahak. Demikian pula dengan kalimat (2b), verba kausatif membuat menyebabkan Rumah mewah (seolah-olah) melakukan sesuatu terhadap pedagang sehingga pedagang selalu mencari untung. Predikat dari komponen akibat yang menyertai verba kausatif membuat tidak hanya berupa verba intransitif dan verba transitif ((1b)-(2b)), tetapi juga berasal dari kategori adjektiva dan nomina, seperti contoh berikut.

(3). a. Badan Renaldi lemah (adjektiva lemah sebagai dasar) b. Pekerjaan seperti itu makin membuat lemah badan Renaldi

c. Pekerjaan seperti itu makin membuat badan Renaldi lemah

(4) a. Kakak sedih. (nomina sedih sebagai dasar)

b. Berita semacam ini selalu membuatnya sedih.

Pada contoh (3) dan (4) di atas, predikat pada konstruksi nonkausatif berupa adjektiva (lemah) dan nomina (sedih). Penambahan argumen penyebab pada konstruksi kausatif analitik ini mengakibatkan perubahan fungsi sintaktis dari argumen-argumen yang terdapat dalam konstruksi nonkausatif karena dalam suatu kalimat tidak memungkinkan adanya dua fungsi subjek, maka kehadiran argumen penyebab pada konstruksi kausatif telah mengubah fungsi subjek pada konstruksi nonkausatif menjadi objek langsung - karena argumen penyebab ini menjadi subjek baru dalam kalimat. Misalnya, pada konstruksi nonkausatif (1a), argumen Renaldi menempati fungsi subjek dalam kalimat intransitif, pada konstruksi kausatif (2b) berubah menjadi objek langsung.

Perubahan fungsi ini disebabkan fungsi subjek sudah diisi oleh argument penyebab, sedangkan fungsi objek langsung masih kosong. Demikian pula dengan konstruksi kausatif (3b) dan (4b), fungsi subjek dalam konstruksi nonkausatif berubah menjadi objek langsung. Sementara pada konstruksi nonkausatif yang predikatnya berupa verba transitif (2a), kehadiran argumen penyebab Rumah mewah mengakibatkan argumen pedagang yang menempati fungsi subjek bergeser menempati fungsi yang masih kosong, menjadi objek tak langsung karena fungsi objek langsung tetap diisi oleh objek langsung pada konstruksi nonkausatif, yaitu argumen untung.

Kausatif analitik dalama bahasa inggris, Menurut Whaley (1997: 289) adalah, "a construction in which multiple verb forms are used to express what can commonly be expressed by a single verb in conjunction with affixes", suatu 
konstruksi di mana bentuk-bentuk verba beragam digunakan untuk mengungkapkan apa yang secara umum diungkapkan oleh sebuah verba dalam konjungsi dengan afiks. Dalam bahasa Inggris misalnya. "he caused/ compelled/forced me to do it. Konstruksi ini memperlihatkan bentuk verba yang cukup beragam, seperti compelled +to do, digunakan untuk mengindikasi sebab yang sering diacu, oleh karena itu disebut peripheral causatives Jika kausativitasnya ditentukan secara analitis, maka konstruksi kausatif perifrastis yang digunakan adalah verba bersusun.

Pertanyaan yang muncul adalah, apakah efek kalimat tersebut langsung atau tidak, dan juga apakah piramida Haiman terjadi dalam bahasa Indonesia?, dan apakah dengan tipe kausatif analitis ini, bentuk verba dalam kalimat menjadi lebih luas, dan 'yang menyebabkan' menjadi kurang langsung. Dalam penjelasan di atas, terlihat bahwa pola kalimat menjadi lebih luas dibandingkan dengan konstruksi kausatif morfologis (adik menjatuhkan buku itu). 'bikin jatuh' terdiri atas dua kata, yang sebenarnya dapat diungkapkan hanya dengan 'menjatuhkan'. Persoalannya adalah bahwa dalam 'bikin jatuh' memperlihatkan sense atau efek tidak langsung bagi pendengar. Jika dilihat melalui piramida Haiman, maka ternyata bahasa Indonesia mengalami apa yang diprediksi dalam piramida ikonisitas Haiman, bahwa bentuk tipe kausatif analitis
(Y Z - "Larger") dalam Y= bikin dan $\mathrm{Z}=$ jatuh, kemudian causation adalah kurang langsung, yaitu membuat jatuh buku, bukan buku langsung jatuh. Dengan contoh kalimat yang sama dalam bahasa Inggris, marilah kita bandingkan contoh (5) berikut ini.

(5) a. I turned off the lamp.

b. I turned the lamp off. (saya mematikan lampu itu)

Baik kalimat (5a) maupun (5b) tidak mengindikasikan ketidaklangsungan, karena turned off dalam bahasa Inggris berarti 'mematikan', kecuali jika kalimat tersebut menggunakan verba cause, yang bukan penanda verba bersusun, contoh:

(6) She caused the lamp off.

(Dia menyebabkan lampu mati)

Tindakan pada 'She' memperlihatkan suatu tindakan yang dilakukan secara sengaja dalam keadaan sadar, artinya tingkat kontrol lebih sedikit, antara verba kausatif sebab (caused), dan off. Dengan contoh ini bukan berarti bahasa Inggris tidak ada dalam prediksi piramida Haiman, ada seperti contoh berikut ini.

(7) Antha caused Viana to sit at the chair.

(Antha menyebabkan Viana duduk di kursi)

'Antha menyebabkan Viana duduk di kursi' memperlihatkan bahwa Antha tidak melakukan dengan sengaja untuk membuat 
Mary duduk di meja. Artinya, tingkat kontrol John lebih sedikit, yang dijelaskan melalui jarak formal antara verba caused dan verba sit.

Contoh lain yang menarik dalam bahasa Inggris, dan bila dibandingkan dengan bahasa Indonesia adalah sebagai berikut:
a. Viana caused her to go to hospital.
(Viana bikin dia pergi ke rumah sakit)
b.Viana bikin dia pergi ke rumah sakit.

Kalimat (8a) mengindikasikan verba bersusun cause+to go, sedangkan (8b) memperlihatkan konstruksi analitis bikin dan pergi. Kedua kalimat di atas menunjukkan efek perbuatan tidak langsung atau kurang langsung. Hampir sama dengan contoh (7), tingkat kontrol viana tidak terlalu menguasai objek, yang dijelaskan melalui jarak formal antara verba caused dan verba. Persamaan kausatif analitik dalam bahasa inggris dan bahasa Indonesia ialah sama-sama menyatakan sebabakibat sedangkan perbedaanya dalam bahasa inggris lebih menonjolkan ke kalimat pasif dan berbeda struktuk kalimatnya dengan bahasa Indonesia.

\section{SIMPULAN}

Konstruksi kausatif bahasa
Indonesia memiliki bentuk
konstruksi kausatif leksikal,
morfologis dan analitis, sedangkan
bahasa Inggris hanya dalam bentuk
konstruksi kausatif leksikal dan

analitis. Dalam bahasa Inggris; dalam konstruksi kausatif periphrastis (analitis), bahasa Inggris lebih banyak menonjolkan keberagaman verba bersusun dibanding bahasa Indonesia, sehingga bahasa Inggris mempunyai hubungan yang "lebih renggang" daripada bahasa Indonesia. Oleh karena itu bentuk kalimat kausatif analitik bahasa inggris dan bahasa Indonesia memiliki perbedaan dalam penyusunan kalimat, dilihat dari adanaya penambahan verba dalam bahasa inggris.

\section{DAFTAR RUJUKAN}

Comrie, Bernard. 1989. Language Universals and Linguistic Typology. Edisi kedua. Oxford: Basil Blackwell.

Dixon, R.M.W. 1994. Ergativity. Cambridge: Cambridge University Press.

Flassy, Don A. L. 1981. Struktur Bahasa Tehid. Jakarta: Pusat Pembinaan dan Pengembangan Bahasa Departemen Pendidikan dan Kebudayaan.

Harimurti. 1996. Pembentukan Kata dalam Bahasa Indonesia. Jakarta: Gramedia.

Haspelmath, Martin. 2002. Understanding Morphology. London: Arnold.

Hopper, Paul J dan Elizabeth Closs Traugott. 2003. Grammaticalization, edisi kedua. Cambridge: Cambridge University Press. 
Sutar Oktaviana Tampubolon, Mulyadi: Konstruksi Kausatif...

Keraf, Gorys. 1990. Linguistik

Bandingan Tipologis. Jakarta:

Gramedia, Kridalaksana.

Kridalaksana, Harimurti. 1996.

Pembentukan Kata dalam

Bahasa Indonesia. Edisi II.

Jakarta: Gramedia Pustaka

Utama.

Sudaryanto. 1983. Predikat-Objek

dalam Bahasa Indonesia:

Keselarasan Pola- Urutan.

Jakarta: Djambatan.

Whaley, Lindsay J. 1997.

Introduction to Typology:

The Unity and Diversity of

Language. California: Sage

Publications.

Winarti, 2009. Konstruksi Kausatif

Morfologis dan Perifrastis

dalam Bahasa Indonesia.

Tesis Magister Universitas

Indonesia. 7 Januari 2009. 